\title{
HIDROLISIS PADA SINTESIS GULA BERBASIS PATI JAGUNG
}

\author{
Hydrolysis in Corn Starch-based Sugar Synthesis \\ Alifia Lulu Salsabilla*, Irsyad Fahruroji \\ Program Studi Pendidikan Teknologi Agroindustri, Universitas Pendidikan Indonesia \\ *alifialulusalsabilla10@upi.edu
}

\begin{abstract}
ABSTRAK
Produksi gula sangat tergantung pada persediaan bahan baku tebu. Salah satu upaya yang dapat dilakukan adalah mencari alternatif sumber bahan baku lain selain tebu. Bahan baku lain yang digunakan adalah jagung. Komposisi utama jagung manis adalah pati, yaitu sekitar $70 \%$ dari bobot biji. Jagung mempunyai kandungan karbohidrat (pati) yang tinggi sehingga berpotensi sebagai bahan dasar pembuatan glukosa. Metode yang digunakan dalam penelitian ini adalah studi literatur. Studi ini bertujuan untuk membandingkan metode hidrolisis asam dan enzimatis untuk produksi gula berbasis pati. Penggunaan metode hidrolisis secara enzimatis lebih baik jika dibandingkan menggunakan asam, karena enzim bekerja secara spesifik sehingga produk yang dihasilkan sesuai dengan yang diinginkan. Selain itu, biaya pemurnian produk lebih mudah dan produk samping yang dihasilkan kecil. Dalam mendapatkan kadar gula pereduksi secara hidrolisis enzimatis, semakin besar volume enzim yang ditambahkan maka semakin besar kadar gula yang dihasilkan. Sementara jika dilakukan secara hidrolisis asam, semakin besar volume asam yang ditambahkan, kadar glukosa yang diperoleh semakin kecil.
\end{abstract}

Kata kunci: Gula, hidrolisis, pati jagung

\begin{abstract}
Sugar production is very dependent on the supply of raw materials for sugar cane. One effort that can be done is to find alternative sources of raw materials other than sugar cane. Another raw material used is corn. The main composition of sweet corn is starch, which is about $70 \%$ of the weight of the seed. Corn has a high carbohydrate (starch) content so that it has the potential as a base for making glucose. The method used in this research is literature study. This study was to compare acid and enzymatic hydrolysis methods for starch-based sugar production. The use of enzymatic hydrolysis method is better than using acid, because the enzyme works specifically so that the resulting product is as desired. In addition, product refining costs are easier and the resulting by-products are small. In obtaining reducing sugar levels by enzymatic hydrolysis, the greater the volume of the enzyme added, the greater the sugar content produced. Meanwhile, if it is carried out by acid hydrolysis, the greater the volume of acid added, the lower the glucose level obtained.
\end{abstract}

Keywords: corn starch, hydrolysis, sugar

\section{PENDAHULUAN}

Indonesia adalah pengimpor gula nomor dua terbesar di dunia. Gula merupakan salah satu kebutuhan pokok bagi masyarakat Indonesia. Sampai saat ini, setiap tahun Indonesia hanya memproduksi 2,1 juta ton gula per tahun. Sementara itu, kebutuhan untuk konsumsi gula mencapai 3 juta ton atau sekitar 12 kilogram per kapita per tahun. Kondisi ini menunjukkan produksi gula hanya mampu mencukupi sekitar 60\% dari kebutuhan nasional (Triyatna, 2012). Melihat kondisi tersebut, pemerintah menerapkan kebijakan mengimpor gula pasir. Impor gula tahun 2020 mencapai 77 ribu ton per tahun. Usaha untuk produksi gula sangat tergantung pada persediaan bahan baku tebu, maka pemerintah seharusnya dapat mencari solusi lain dalam upaya pemenuhan kebutuhan gula masyarakat. Salah satu upaya yang dapat dilakukan adalah mencari alternatif sumber bahan baku lain selain tebu. Bahan baku lain yang digunakan adalah jagung. 
Jagung sebagai sumber bahan pangan telah dimanfaatkan untuk makanan pokok (beras jagung) di daerah tertentu, makanan penyela (jagung rebus dan bakar), makanan kecil (berondong, tortilla), tepung, kue, roti dan bubur. Kegunaan lain adalah untuk makanan terna dan bahan baku industri pati, glukosa, sirup, dekstrin, alkohol dan minyak. Pati jagung berpotensi mensubstitusi terigu maupun tapioka dari $20-100 \%$. Jika pati jagung menggantikan $10 \%$ saja, maka diperlukan $0,3-1,0$ juta ton pati jagung per tahun. Pati jagung memiliki prospek pengembangan menjadi produk-produk olahan bagi industri-industri yang menghasilkan tepung maizena, dekstrin dan gula jagung (Maflahah, 2010).

Pada dasarnya gula diperoleh dari hidrolisis pati. Hidrolisis pati dapat dilakukan dengan dua metode, yaitu hidrolisis asam dan hidrolisis enzimatis. Metode hidrolisis merupakan proses untuk mendapatkan sirup glukosa dari pati. Metode hidrolisis dapat dilakukan dengan cara hidrolisis asam, hidrolisis secara enzimatis dan gabungan antara hidrolisis enzim dan asam. Hidrolisis enzimatis memiliki beberapa keuntungan, yaitu kondisi prosesnya dapat dikontrol, biaya pemurnian lebih murah, dihasilkan lebih sedikit abu dan produk samping, dan kerusakan warna dapat diminimalkan. Pada hidrolisis pati secara enzimatis untuk menghasilkan sirup glukosa, enzim yang dapat digunakan adalah amilase, dan asam yang biasa digunakan adalah $\mathrm{HCl}$ (Triyono,2009).

\section{METODE}

Metode yang digunakan dalam penelitian ini adalah litelatur review dari berbagai sumber yang relevan. Prosesnya terdiri dari empat tahap yaitu designing the review, conducting the review, analysis dan writing the review (Snyder, 2019). Designing the review, dalam tahap ini dilakukan pencarian litelatur secara luas yang relevan mengenai hidrolisis asam dan enzimatis pati jagung berfokus pada artikel atau laporan penelitian yang diterbitkan dari tahun 2005 hingga 2020. Selain itu, litelatur juga berasal dari jurnal yang dipublikasikan atau tidak dipublikasikan menggunakan mesin pencarian seperti Google dan Google scholar. Dalam tahapan ini menghasilkan lebih dari 30 referensi jurnal. Conducting the review, dalam proses ini dilakukan review jurnal yang telah terkumpul dengan cara melakukan review secara bertahap dengan membaca abstrak terlebih dahulu dan membuat pilihan dan kemudian menyeleksi jurnal yang sesuai dengan topik. Tahapan ini didapatkan lebih 20 referensi jurnal. Analysis, setelah melakukan tinjauan pustaka dan memutuskan sampel akhir, dilakukan pertimbangan bagaimana artikel yang akan digunakan untuk melakukan analisis yang sesuai. Writing the review, yaitu penulisan yang dilakukan sesuai dengan topik bahasan utama. Masing-masing topik ditulis dengan litelature sintesis sehingga dapat menjawab tujuan penelitian.

\section{HASIL DAN PEMBAHASAN}

\section{Hidrolisis Asam}

Komposisi utama jagung manis adalah pati, yaitu sekitar 70\% dari bobot biji (Prambudi, 2008). Jagung mempunyai kandungan karbohidrat (pati) yang tinggi sehingga berpotensi sebagai bahan dasar pembuatan glukosa. Pati merupakan polimer dari glukosa, dapat dipecah menjadi gula lebih sederhana menggunakan hidrolisis asam. Hidrolisis asam pertama kali ditemukan pada abad-19 oleh Kirchoff seorang ahli kimia jerman. Kirchoff membuat sirup manis dari perebusan bahan pati gandum dengan menggunakan asam sulfat encer (Dziedzic \& Kearsley, 1995).

Proses hidrolisis asam terjadi dalam dua tahap penyerangan pada granula pati, yaitu tahap penyerangan secara cepat pada bagian amorf dan tahap penyerangan yang lebih lambat pada bagian kristalin pada fraksi amilopektin (Winarti, 2014). Hidrolisis didaerah amorf dipengaruhi oleh ukuran granula, pori-pori permukaan, kandungan amilosa, dan jumlah kompleks lipid rantai amilosa. Sementara hidrolisis daerah kristalin dipengaruhi oleh kandungan amilopektin, dan derajat kerapatan ikatan heliks ganda di daerah kristalin (Le corre, dkk., 2010). Hidrolisis asam tidak mengubah bentuk granula tetapi menyebabkan penurunan kemampuan mengembang (swelling) dan viskositas serta viskositas puncak, selain itu meningkatkan kestabilan pasta pati selama proses gelatinisasi (Ferrini et al., 2008)

Beberapa faktor yang mempengaruhi efektifitas hidrolisis asam adalah jenis substrat, rasio bahan, waktu, suhu, dan konsentrasi asam (Manna, dkk., 2020). Semakin halus dan luas permukaan substrat, kontak antar substrat dengan asam akan semakin luas, sehingga meningkatkan kecepatan 
reaksi dan memperkecil kenversi reaksi (Utani, dkk., 2014). Semakin besar rasio bahan, bahan yang bereaksi dengan larutan akan semakin besar dan memberikan hasil yang lebih banyak (Utani, dkk., 2014).

Hidrolisis pati menggunakan asam memerlukan suhu yang tinggi yaitu antara $140-160^{\circ} \mathrm{C}$ (Budiarti, 2016). Proses hidrolisis berpengaruh terhadap suhu, semakin tinggi suhu hidrolisisnya maka daya serap air semakin meningkat. Semakin tinggi suhu hidrolisis pati menggunakan asam menyebabkan semakin tinggi kadar gula reduksi yang dihasilkan, karena pati dengan suhu tinggi maka pati lebih cepat menggelembung dan mudah pecah sehingga ikatan antar unti glukosa dari amilosa dan amilopektin meregang dan lepas menghasilkan rantai pendek unit-unit glukosa (Susanto, et al. 2014).

Banyak penelitian yang mengkaji pengaruh interaksi antara setiap faktor yang berpengaruh pada proses hidrolisis. Penelitian Manna (2020), menunjukan Total gula hasil hidrolisis limbah menggunakan asam sulfat pekat dengan berbagai konsentrasi pada suhu $80^{\circ} \mathrm{C}$ dan suhu $121^{\circ} \mathrm{C}$. Manna, dkk.(2020), menambahkan bahwa perlakuan terbaik adalah hidrolisis dengan $1 \% \mathrm{H}_{2} \mathrm{SO}_{4}$ pada $121^{\circ} \mathrm{C}$ selama 60 menit. Penelitian lain tentang hidrolisis asam terlihat pada tabel 1.

Tabel 1. Hidrolisis asam pada berbagai jenis pati

\begin{tabular}{|c|c|c|c|c|c|}
\hline $\begin{array}{l}\text { Jenis } \\
\text { Pati }\end{array}$ & Asam & Suhu & Waktu & Hal yang ditemukan & Referensi \\
\hline $\begin{array}{l}\text { Pati } \\
\text { Kacang } \\
\text { Polong }\end{array}$ & $\begin{array}{c}\text { Asam Klorida } \\
2 \%\end{array}$ & $45^{\circ} \mathrm{C}$ & $\begin{array}{l}0,5-2,5 \\
\text { jam }\end{array}$ & $\begin{array}{l}\text { Berat molekul amilopektin } \\
\text { menurun, dan peningkatan } \\
\text { kristalin. }\end{array}$ & $\begin{array}{l}\text { Zhang, dkk. } \\
\text { (2019) }\end{array}$ \\
\hline $\begin{array}{l}\text { Pati } \\
\text { Jagung }\end{array}$ & $\begin{array}{c}\text { Asam Klorida } \\
0,1 \mathrm{~N}\end{array}$ & $121^{\circ} \mathrm{C}$ & 90 menit & $\begin{array}{l}\text { Rendemen gula cair hasil } \\
\text { hidrolisis secara asam } \\
\text { sebesar } 78,55 \% \text { pada } \\
\text { konsentrasi HCL } 1,0 \mathrm{~N} \text {. }\end{array}$ & $\begin{array}{l}\text { Sutamihardja } \\
\text {, dkk. (2017) }\end{array}$ \\
\hline $\begin{array}{l}\text { Pati } \\
\text { Jagung }\end{array}$ & $\mathrm{HCL} 0,5 \mathrm{~N}$ & $60^{\circ} \mathrm{C}$ & 0-3 jam & $\begin{array}{l}\text { Perlakuan terbaik adalah } \\
\text { hidrolisis selama } 2 \text { jam. }\end{array}$ & Wang, (2017) \\
\hline $\begin{array}{l}\text { Pati } \\
\text { Jagung }\end{array}$ & $\begin{array}{c}\text { Asam Klorida } \\
2,2 \mathrm{~N}\end{array}$ & $36^{\circ} \mathrm{C}$ & $\begin{array}{c}3,8,15 \\
\text { hari }\end{array}$ & $\begin{array}{c}\text { Daerah amorf pati } \\
\text { terhidrolisis sempurna, dan } \\
\text { meningkatkan daya cerna } \\
\text { pati. }\end{array}$ & $\begin{array}{l}\text { Miao, dkk. } \\
\quad(2011)\end{array}$ \\
\hline $\begin{array}{l}\text { Pati } \\
\text { Singkong }\end{array}$ & $\begin{array}{c}\mathrm{HCl}(0,25 \mathrm{~N} \\
0,5 \mathrm{~N}, 0,75 \mathrm{~N})\end{array}$ & $121^{\circ} \mathrm{C}$ & $\begin{array}{c}30,60 \\
\text { dan } 90 \\
\text { menit }\end{array}$ & $\begin{array}{c}\text { Kadar gula tertinggi diperoleh } \\
\text { pada konsentrasi HCL } 0,5 \mathrm{~N} \\
\text { dan waktu hidrolisis } 90 \text { menit } \\
\text { sebesar } 84,22 \% .\end{array}$ & $\begin{array}{l}\text { Sutamihardja } \\
\text {, dkk. (2017) }\end{array}$ \\
\hline $\begin{array}{l}\text { Pati Ubi } \\
\text { Talas }\end{array}$ & $\mathrm{HCl} 7 \%$ & $\begin{array}{l}80^{\circ} \mathrm{C} \\
90^{\circ} \mathrm{C} \\
100^{\circ} \mathrm{C}\end{array}$ & 60 menit & $\begin{array}{l}\text { Kadar gula reduksi paling } \\
\text { tinggi } 3,06 \% \text {, total gula } 5,64 \% \\
\text { dan nilai } D E 54,24 \% \text {. Total } \\
\text { padatan terlarut } 5,15^{\circ} \text { Brix dan } \\
\text { kejernihan } 0,02 \text {. Perlakuan } \\
\text { suhu dan jenis asam yang } \\
\text { menghasilkan glukosa terbaik } \\
\text { adalah pada suhu } 100^{\circ} \mathrm{C} \text {. }\end{array}$ & $\begin{array}{l}\text { Dewi, N. K. } \\
\text { A., dkk. } \\
(2018)\end{array}$ \\
\hline $\begin{array}{l}\text { Pati Ubi } \\
\text { Jalar }\end{array}$ & $\begin{array}{l}\mathrm{HCl} 0,5 \mathrm{~N}(10 \\
\mathrm{ml}, 15 \mathrm{ml}, 30 \\
\mathrm{ml})\end{array}$ & $100^{\circ} \mathrm{C}$ & $\begin{array}{l}30 \text { menit } \\
45 \text { menit } \\
60 \text { menit }\end{array}$ & $\begin{array}{c}\text { Semakin lama waktu } \\
\text { hidrolisis, semakin rendah } \\
\text { kadar glukosa yang } \\
\text { dihasilkan. Semakin besar } \\
\text { volume } \mathrm{HCl} \text {, kadar glukosa } \\
\text { yang diperoleh semakin kecil. } \\
\text { Kadar glukosa tertinggi } \\
\text { 62,76\% diperoleh pada waktu }\end{array}$ & $\begin{array}{l}\text { Shitophyta, } \\
\text { L. M., dkk. } \\
\text { (2020). }\end{array}$ \\
\hline
\end{tabular}




\begin{tabular}{|c|c|c|c|c|c|}
\hline $\begin{array}{l}\text { Jenis } \\
\text { Pati }\end{array}$ & Asam & Suhu & Waktu & Hal yang ditemukan & Referensi \\
\hline & & & & $\begin{array}{l}\text { hidrolisis } 30 \text { menit dan } \\
\text { volume } \mathrm{HCl} 15 \mathrm{ml} .\end{array}$ & \\
\hline $\begin{array}{l}\text { Pati Ubi } \\
\text { Garut }\end{array}$ & $\mathrm{HCl} 2,2 \mathrm{~N}$ & $35^{\circ} \mathrm{C}$ & 2 jam & $\begin{array}{l}\text { Adanya pemotongan titik } \\
\text { percabangan amilopektin. }\end{array}$ & $\begin{array}{l}\text { Faridah, dkk. } \\
\qquad(2010)\end{array}$ \\
\hline $\begin{array}{c}\text { Pati } \\
\text { Kentang }\end{array}$ & $\begin{array}{c}\mathrm{HCl}(0,5 \mathrm{~N}, 1 \mathrm{~N} \\
1,5 \mathrm{~N}, 2 \mathrm{~N})\end{array}$ & $\begin{array}{l}120- \\
140^{\circ} \mathrm{C}\end{array}$ & $\begin{array}{l}30 \text { menit } \\
60 \text { menit }\end{array}$ & $\begin{array}{l}\text { Semakin besar konsentrasi } \\
\mathrm{HCl} \text { yang berfungsi sebagai }\end{array}$ & $\begin{array}{l}\text { Utami, R. S, } \\
\text { dkk. (2014) }\end{array}$ \\
\hline & & & $\begin{array}{l}90 \text { menit } \\
120 \\
\text { menit }\end{array}$ & $\begin{array}{l}\text { katalis, maka nilai konstanta } \\
\text { kecepatan reaksi juga } \\
\text { semakin besar. } \\
\text { Semakin lama waktu yang } \\
\text { digunakan untuk hidrolisa } \\
\text { maka semakin bertambah } \\
\text { perolehan glukosa. }\end{array}$ & \\
\hline $\begin{array}{c}\text { Pati } \\
\text { Pisang } \\
\text { Tanduk }\end{array}$ & $\mathrm{HCl} 2,5 \mathrm{~N}$ & $90^{\circ} \mathrm{C}$ & 10 menit & $\begin{array}{l}\text { Semakin besar konsentrasi } \\
\mathrm{HCl} \text {, maka semakin besar } \\
\text { pula konstanta kecepatan } \\
\text { reaksi. }\end{array}$ & $\begin{array}{l}\text { Yuniwati, M. } \\
\text { (2011) }\end{array}$ \\
\hline
\end{tabular}

\section{Hidrolisis Enzimatis}

Hidrolisis enzimatis adalah proses konversi selulosa dan hemiselulosa menjadi gula reduksi menggunakan enzim. Enzim yang digunakan untuk mengkonversi hemiselulosa menjadi glukosa adalah enzim xylanase sedangkan enzim yang digunakan untuk mengonversi selulase menjadi glukosa menggunakan enzim selulase.

Enzim selulase digunakan untuk menghidrolisis selulosa menjadi glukosa. Hidrolisis secara enzimatis lebih menguntungan dibandingkan dengan hidrolisis asam, karena enzim akan memutus ikatan glikosida secara spesifik, kerusakan warna dapat diminimalkan dan tidak menyisakan residu. Selain itu, hidrolisis secara enzimatis dapat dilakukan dengan menggunakan enzim $\alpha$-amilase, glukoamilase dan pulullanase.

\section{Enzim penghidrolisis pati}

\section{a. Enzim $\alpha$-amilase}

Enzim $\alpha$-amilase adalah enzim yang memecah ikatan dalam $\alpha-1,4$-glycosidic pati menjadi produk berupa glukosa dan maltosa. Enzim a-amilase dibedakan menjadi dua golongan yaitu termostabil (tahan panas) dan termolabil (tidak tahan panas). Enzim $\alpha$-amilase yang termasuk kedalam golongan termostabil dapat diperoleh dari Bacillus lichenoformis, Bacillus subtilis, Bacillus stearothermophilus dan Bacillus amyloliquefaciens, sedangkan yang termasuk termolabil dihasilkan dari jenis jamur seperti Aspergilus oryzae dan Aspergilus niger (Rahmawati dkk, 2015). Enzim aamilase juga dapat diperoleh dari tanaman dan hewan. Enzim $\alpha$-amilase ini sangat berperan dalam industri pembuatan roti dan sirup. Enzim a-amilase banyak terdapat pada kecambah kacang kacangan (Suarni dkk, 2007).

Keberhasilan isolasi dan pengujian aktivitas enzim tergantung pada macam serta kondisi sumber enzim, letak enzim, kecermatan kerja, bahan dan cara ekstraksi yang dipergunakan serta pengertian sifat enzim tersebut. Enzim $\alpha$-amilase termasuk ekstraselular, sehingga mengekstraknya relatif mudah (Suarni dkk, 2007). Enzim a-amilase termodifikasi dapat bekerja pada suhu hingga 105$110^{\circ} \mathrm{C}$ dengan kisaran pH 5.1-5.6 selama 60-180 menit (Sivaramakrishnan, dkk 2006).

Aktivitas enzim $\alpha$-amilase dipengaruhi oleh beberapa faktor diantaranya adalah $\mathrm{pH}$ dan suhu. Enzim a-amilase mempunyai kondisi optimum pada suhu $90-105^{\circ} \mathrm{C}$ dengan kisaran $\mathrm{pH}$ 5.6-6.0. suhu yang terlampau tinggi dari kondisi optimum akan menggangu dan merusak enzim, sedangkan pemberia suhu yang terlampau rendah dari kondisi optimum akan menyebabkan gelatinisasi pati tidak sempurna (Richardson et al, 2002). Dalam mendapatkan kadar gula pereduksi volume enzim a- 
amilase yang ditambahkan berpengaruh terhadap kadar gula pereduksi yang dihasilkan. Semakin besar volume enzim yang ditambahkan, maka akan semakin besar kadar gula pereduksi yang dihasilkan dan masih ada kemungkinan kadar gula pereduksi naik apabila volume enzim ditingkatkan atau akan berubah konstan pada batas-batas volume tertentu. (Rahmawati dkk, 2015).

Penggunaan metode hidrolisis secara enzimatik lebih baik jika dibandingkan menggunakan asam, karena enzim bekerja secara spesifik sehingga produk yang dihasilkan sesuai dengan yang diinginkan. Selain itu, biaya pemurnian produk lebih mudah dan produk samping yang dihasilkan kecil (Turah dkk, 2017).

\section{b. Enzim Glukoamilase}

Enzim Glukoamilase dikenal juga dengan amiloglukosidase, pada hidrolisis pati enzim glukoamilase berfungsi untuk memecah ikatan $\alpha-(1,4)$ glikosidik dan $\alpha-(1,6)$ glikosidik pada pati. Glukoamilase dapat dihasilkan dari jamur: Aspergillus sp, Rhizopus oryzae, Rhizopus niveus, dari yeast: Saccharomycopsis fibuligera, Saccharomyces diasticus, dan dari bakteri: Clostridium acetobutylicum (Reilly, 2003). Glukoamilase murni banyak digunakan untuk pembuatan sirup glukosa dari maltodekstrin yang diproduksi oleh $\alpha$-amilase dari pemurnian pati (Rahmawati, dkk 2015).

Enzim glukoamilase biasa digunakan dalam hidrolisis pati pada tahap sakarifikasi. Dalam penelitian sutamihardja (2019), pada tahap sakarifikasi yang menggunakan enzim glukoamilase menunjukkan terjadinya peningkatan kadar gula pereduksi. Adanya peningkatan kadar gula pereduksi ini disebabkan pada saat tahap sakarifikasi terjadi proses hidrolisis maltose dan dekstrin menjadi glukosa oleh enzim glukoamilase yang tidak hanya mampu memutus ikatan $\alpha-(1,4)$ glikosidik tetapi juga mampu menghidrolisis ikatan $\alpha-(1,6)$ glikosidik, sehingga proses hidrolisis berlangsung maksimal (Risnoyatiningsih, 2011). Kerja enzim glukoamilase dipengaruhi oleh beberapa faktor yaitu suhu, $\mathrm{pH}$, dan waktu reaksi yang diperlukan. Suhu optimum untuk kerja enzim ini adalahh $40-60^{\circ} \mathrm{C}$, dengan nilai $\mathrm{pH}$ optimum untuk aktvitas ini adalah 4.5 dan waktu reaksi yang diperlukan untuk hidrolisa pati sekitar 48-96 jam (Rahmawati, dkk 2015).

\section{c. Enzim Pullulanase}

Pullulanase adalah eksoenzim yang mengkatalisis hidrolisis $\alpha-1,6$-penghubung pullulan dan polisakarida lain untuk menghasilkan maltotriosa sebagai produk akhir. Pullulanase dengan enzim $\alpha$ amilase dapat bersinergis menghasilkan pemotongan molekul karbohidrat yang sempurna. Pullulanase adalah protein monomer dengan massa molekul di kisaran 60-140 kDa. Enzim ini dapat diperoleh pada ekstrak beras dan kacang-kacangan (Erianti, 2004). Selain dari tanaman, pullulanase dapat dihasilkan dari bakteri mesofilik, seperti Klebsiella, Escherichia coli, Streptococcus, Bacillus, dan Streptomyces. Pullulanase yang dihasilkan oleh bakteri mesofilik merupakan enzim yang bersifat tidak tahan oleh suhu tinggi. Suhu maksimum yang dikehendaki adalah $60^{\circ} \mathrm{C}$. Jika suhu yang digunakan lebih dari suhu maksimum, maka enzim akan terdenaturasi. Namun beberapa pullulanase ada yang mampu bertahan pada suhu tinggi, seperti pullulanase yang dihasilkan oleh bakteri Thermus caldaphilus yang masih bisa bertahan pada suhu $90^{\circ} \mathrm{C}$ (Rahmawati, dkk 2015). Hidrolisa pati menjadi sirup glukosa melalui tiga tahapan, yaitu gelatinisasi, likuifikasi dan sakarifikasi. Gula cair hasil hidrolisis enzim optimum semakin rendah kadar air gula cair maka kualitas gula cair tersebut semakin baik karena nilai viskositasnya tinggi sehingga gula cair tersebut semakin kental.

\section{a. Gelatinisasi}

Gelatinisasi merupakan proses awalan sebelum likuifikasi. Gelatinisasi adalah proses pembengkakan granula pati akibat pemanasan yang memutus ikatan hidrogen pada ikatan glikosida pati. Pembengkakan granula tersebut bersifat irreversible atau tidak bisa kembali lagi ke bentuk semula. Likuifikasi yang dilakukan tanpa gelatinisasi terlebih dahulu akan membutuhkan waktu yang lebih lama dibandingkan dengan substrat yang telah mengalami gelatinisasi (Mitsuki,2005).

\section{b. Likuifikasi}


Likuifikasi merupakan proses pencairan gel pati yang memiliki viskositas tinggi ke viskositas yang lebih rendah dengan menghidrolisis pati menjadi molekul-molekul yang lebih kecil dari oligosakarida atau dekstrin dengan menggunakan enzim a-amilase. Dalam proses tersebut granula pati yang semula tidak larut, dipanaskan sampai mengembang dan rusak, sehingga dapat tersebar ke dalam larutan dan proses tersebut dikatakan baik bila viskositas larutan yang dihasilkan makan kecil (Sun et al., 2010). pH optimum pada tahap gelatinisasi dan likuifikasi menggunakan enzim aamilase adalah 5.3-6.5 (Yunianta, 2010). Aktivitas enzim a-amilase menentukan cepat lambatnya proses likuifikasi. Enzim ini akan bekerja lebih cepat jika menggunakan substrat yang berbentuk gel atau yang sebelumnya telah digelatinisasi.

\section{c. Sakarifikasi}

Sakarifikasi merupakan tahap hidrolisis lanjutan dari dekstrin hasil likuifikasi dengan penambahan enzim glukoamilase yang dilakukan pada temperatur $55-66^{\circ} \mathrm{C}, \mathrm{pH} 4-4.5$ selama $24-72$ jam. Enzim glukoamilase akan menghidrolisis pati menjadi oligosakarida, matotriosa menjadi maltosa dan menghidrolisa maltosa menjadi glukosa. Untuk membantu proses hidrolis titik percabangan, maka biasanya ditambahkan enzim yang spesifik yaitu pullulanase. Kombinasi antara glukoamilase dan pullulanase sering dinamakan dengan enzim dextrozyme.

Proses likuifikasi dan sakarifikasi pada pembuatan gula dipengaruhi oleh beberapa faktor seperti pH, suhu, konsentrasi enzim, dan lama inkubasi (Rahmawati dkk, 2015).

\section{KESIMPULAN}

Penggunaan metode hidrolisis secara enzimatis lebih baik jika dibandingkan menggunakan asam, karena enzim bekerja secara spesifik sehingga produk yang dihasilkan sesuai dengan yang diinginkan. Selain itu, biaya pemurnian produk lebih mudah dan produk samping yang dihasilkan kecil. dalam mendapatkan kadar gula pereduksi secara hidrolisis enzimatis, semakin besar volume enzim yang ditambahkan maka semakin besar kadar gula yang dihasilkan. Sementara jika dilakukan secara hidrolisis asam, semakin besar volume asam yang ditambahkan, kadar glukosa yang diperoleh semakin kecil.

\section{DAFTAR PUSTAKA}

Dewi, N. K. A., Hartiati, A., \& Harsojuwono, B. A. (2018). Pengaruh suhu dan jenis asam pada hidrolisis pati ubi talas (Colocasia esculenta L. Schott) terhadap karakteristik glukosa. Jurnal Rekayasa Dan Manajemen Agroindustri, 6(4), 307-315.

Dziedzic, S. Z. \& W Kearsley, M., (1995). Handbook of starch hydrolysis products and their derivatives. Boston, USA: Springer zic.

Erianti, L. (2004). Kajian Hidrolisis Pati Garut Menggunakan Enzim a-Amilase dan Kombinasi Enzim a-Amilase dan Pullulanase dalam Proses Produksi Siklodekstrin. Skripsi. Fateta IPB. Bogor.

Faridah, D. N., Fardiaz, D., Andarwulan, N., \& Sunarti, T. C. (2010). Perubahan Struktur Pati Garut (Maranta arundinaceae) sebagai Akibat Modifikasi Hidrolisis Asam, Pemotongan Titik Percabangan dan Siklus Pemanasan-Pendinginan [Structure Changes of Arrowroot (Maranta arundinaceae) Starch as Influenced b. Jurnal Teknologi dan Industri Pangan, 21(2), 135-135.

Ferrini LMK, Rochaa TS, Demiate IM, Franco CLM. (2008). Effect of acid methano, treatment on the physicochemical and structural characteristics of cassava and maize starch. Starch/Starke. 60,417-425.

Maflahah, I. (2010). Analisis proses pembuatan pati jagung (maizena) berbasis neraca massa. Jurnal Embryo, 7(1), 40-45.

Miao, M. e. a., (2011). Impact of mild acid hydrolysis on structure and digestion properties of waxy maize starch. Food Chemistry, 126(2), 505-513.

Mitsuiki S, M. K. S. M. G. M. H. S. F. K., 2005. Comparative Characterization of Raw Starch Hydrolizing a Amylase from Various Bacillus Strains. J. Enzmic Tech , Volume 37, pp. 410- 
416.

Rahmawati A. Y, S. A., (2015). Hidrolisis Tepung Ubi Jalar Ungu (Ipomea Batatas L.) Secara Enzimatis Menjadi Sirup Glukosa Fungsional: Kajian Pustaka. Jurnal Pangan dan Agroindustri, 3(3),1152-1159.

Richardson, T.H, Tan, X., Frey, G., Callen, W., Cabell, M., Lam, D. Macomber, J., Short, J.M., Robertson, D.E., and Miller, C. (2002). A Novel, High Performance Enzyme for Starch Liquefaction Discovery and Optimization of a Low pH, Thermostable a Amylase. J. Biol Chem 227, 26501-26507

Risnoyatiningsih, S. (2011). Hidrolisis Pati Ubi Jalar Kuning Menjadi Glukosa Secara Enzimatis. Jurnal Teknik Kimia. Vol 5(2), 417-424.

Reilly, R. G. I. J. W. A. V. a. D. W. (2003). Handbook of Food Enzymology, Inc. New York: Marcell Dekker.

Robi'a, R. \& Sutrisno, A. 2015. Karakteristik Sirup Glukosa Dari Tepung Ubi Ungu (Kajian Suhu Likuifikasi Dan Konsentrasi a-Amilase): Kajian Pustaka [In Press September 2015]. Jurnal Pangan dan Agroindustri, 3.

Shitophyta, L. M., Ardiansyah, D. S., \& Nendanov, M. R. (2020). Pemanfaatan Ubi Jalar (Ipomoea Babatas, L.) Menjadi Sirup Glukosa Dengan Hidrolisis Asam. Jurnal Penelitian Sains, 22(1), 45-49.

Sivaramakrishnan S, G. D. N. K. S. C. P. A., (2006). a-Amilase From Microbial Sources An Overview on Recent Developments. Journal of Food Technology and Biotechnologi, 44(2),173-184.

Snyder, H. (2019). Literature review as a research methodology: An overview and guidelines. Journal of Business Research, 104, 333-339.

Suarni., \& R. Patong. (2007). Potensi Kecambah Kacang Hijau sebagai Enzim A-Amilase. Indo. J. Chem. 7(3), 332-336.

Sun, J., Zhao, R., Zeng, J., LI, G. \& LI, X. 2010. Characterization of Destrins with Different Dextrose Equivalents. 15, 5162- 5173.

Sutamihardja, R. T. M., Azizah, M., \& Mafiana, B. D. (2017). Perbandingan Hidrolisis Enzimatis Dan Asam Terhadap Pati Jagung Manis (Zea Mays L.) Dalam Pembuatan Gula Cair. Jurnal Sains Natural, 7(2), 58-67.

Sutamihardja, R. T. M., Srikandi, S., \& Herdiani, D. P. (2017). Hidrolisis Asam Klorida Tepung Pati Singkong (Manihot Esculenta Crantz) Dalam Pembuatan Gula Cair. Jurnal Sains Natural, 5(1), 83-91.

Triyatna SO. (2012). Produksi Gula Hanya 60 Persen Kebutuhan. http://bisniskeuangan.kompas.com.

Triyono, A. (2009). Komposisi Gula Glukosa dari Hasil Hidrolisis Pati Ubi Jalar (Ipomea batatas, L) dalam Upaya Pemanfaatan Pati Umbi-umbian. B2PTTG-LIPI. Subang

Turah, N., Bahri, S., \& Nurakhirawati, N. (2017). Penentuan Waktu Paruh Enzim Amilase Amobil Dari Kecambah Kacang Hijau (Phaseolus Aureus) Pada Produksi Glukosa Dari Maltodekstrin. KOVALEN: Jurnal Riset Kimia, 3(2), 150-157.

Utami, R. S., Sari, E. P., \& Inayati, I. (2014). Pengaruh waktu hidrolisa dan konsentrasi asam pada hidrolisa pati kentang dengan katalis asam. EKUILIBRIUM Journal of Chemical Engineering, 13(2), 45-49.

Winarti, C., Richana, N., Mangunwidjaja, D., \& TIP, T. C. S. (2014). Pengaruh lama hidrolisis asam terhadap karakteristik fisiko-kimia pati garut. Journal of Agroindustrial Technology, 24(3),218225.

Yunianta, S. T. A. d., 2010. Hidrolisis Secara Sinergis Pati Garut (Marantha Arundinaceae L.) Oleh Enzim a-Amilase, Glukoamilase, Dan Pullulanase Untuk Produksi Sirup Glukosa. Jurnal Teknologi Pertanian, 11(2), pp. 78-86.

Yuniwati, M., Ismiyati, D., \& Kurniasih, R. (2011). Kinetika reaksi hidrolisis pati pisang tanduk dengan katalisator asam chlorida. Jurnal Teknologi, 4(2), 106-112.

Zhang, H., Hou, H., Liu, P., Wang, W., \& Dong, H. (2019). Effects of acid hydrolysis on the physicochemical properties of pea starch and its film forming capacity. Food Hydrocolloids, 87, 173-179. 